\title{
PENGARUH MEDIA TANAM TERHADAP PERTUMBUHAN STEK MAWAR PAGAR (Rosa multiflora)
}

\author{
Reza Fahmi ${ }^{1}$ \\ Dosen Program Studi Kehutanan Fakultas Pertanian Universitas Almuslim Bireuen \\ Email: fahmi_reza12@yahoo.com.
}

\begin{abstract}
Abstrak
Penelitian ini bertujuan untuk mengetahui Pengaruh media tanam terhadap pertumbuhan stek mawar pagar (Rosa multiflora). Penelitian ini akan dilaksanakan di Gampong Panton Mesjid Kecamatan Makmur Kabupaten Bireuen dari bulan Maret sampai dengan Mei 2018. Rancangan yang dilakukan dalam penelitian ini adalah Rancangan Acak Kelompok (RAK) Non Faktorial dengan perlakuan yaitu: penggunaan media tanam yang terdiri dari 3 taraf yaitu: $\mathbf{M}_{0}=$ Sekam, $\mathbf{M}_{1}=$ Tanah + Sekam, $\mathbf{M}_{2}=$ Tanah + sekam + pupuk kandang. Pengamatan terdiri dari : umur muncul tunas, panjang tunas, jumlah tunas, panjang akar, jumlah akar, jumlah daun dan persentase stek yang tumbuh. Hasil penelitian menunjukkan bahwa media tanam berpengaruh sangat nyata terhadap pertumbuhan panjang tunas, jumlah tunas, jumlah daun, jumlah akar, panjang akar pada umur 30 HST dan 60 HST dan persentase stek yang tumbuh. Perlakuan terbaik dijumpai pada perlakuan menggunakan media tanam tanah dan sekam $\left(\mathrm{M}_{1}\right)$.
\end{abstract}

Kata Kunci: Media tanam, pertumbuhan stek, mawar. 


\section{PENDAHULUAN}

Mawar merupakan salah satu tanaman hias kebanggaan Indonesia dan sangat populer dimata dunia karena memiliki bunga yang cantik, indah dan menarik. Selain itu juga memiliki nilai ekonomi dan sosial yang tinggi untuk dijadikan komoditas perdagangan dan komersil. Permintaan mawar terus meningkat seiring dengan meningkatnya permintaan masyarakat. Mawar dapat dibudidaya sebagai bunga potong, tanaman penghias taman, dan sebagai bunga pot.

Bunga mawar dikenal mempunyai banyak varietas sehingga disebut Rosaceae atau keluarga mawar mawaran. Kemajuan teknologi semakin membuat tanaman bunga mawar beraneka ragam dengan warna warninya mulai dari merah, ungu, hitam dan bahkan campuran beberapa warna. Disamping itu kelopak bunganya juga semakin variatif, dari yang berkuntum tunggal, ganda sampai yang bertumpuk (Alamanda, 2009).

Pertumbuhan tanaman mawar sangat dipengaruhi oleh ketersediaan air dan unsur hara. Untuk itulah media tanam yang baik sangat diperlukan untuk mendukung pertumbuhan tanaman. Media tanam berfungsi sebagai tempattumbuh dan berkembangnya akar serta menahan unsur hara dan air sementara waktu. Jenis dan sifat media tanam akan mempengaruhi ketersediaan unsur hara dan air di daerah perakaran. Beberapa macam media berbeda pengaruhnya terhadap pertumbuhan dan hasil tanaman. Perbedaan ini berhubungan dengan daya mengikat air dan unsur hara bagi tanaman serta porositas, kelembaban dan aerasi dalam media tanam (Hardjowigeno, 2003).

Pada masa sekarang, media tanam yang sering digunakan, selain tanah untuk tanaman pot, misalnya kompos daun bambu adalah kompos pinus, kompos tandan kosong kelapa sawit, serutan kayu, sekam padi, bagas tebu, serbuk sabut kelapa, dan zeolit (Wuryaningsih $d k k$., 2013). Media tanam tanpa tanah mempunyai peluang untuk dikembangkan karena lebih bersih, ramah lingkungan, dan bahan-bahannya tersedia di alam Indonesia (Wuryaningsih $d k k$., 2013).

Pupuk kandang sapi sering digunakan sebagai media tanam karena pupuk kandang sapi merupakan bahan organik yang mengalami proses dekomposisi oleh mikroorganisme pengurai, disamping itu pupuk kandang sapi mempunyai sifat fisik yang baik, diantaranya porus, menahan air, dan nutrisi tanaman dengan baik. Sekam adalah hasil penggilingan padi dan hasil limbah pertanian yang baik digunakan untuk media tanam karena mempunyai sifat fisik yang baik .

Faktor fisik seperti panjang stek dan diameter stek merupakan hal yang harus diperhatikan yang berpengaruh terhadap kemampuan bahan setek membentuk akar. Panjang dan diameter setek yang baik sebagai bahan perbanyakan adalah batang pada percabangan lateral (primer dan sekunder), semakin menjauh dari pucuk maka diameter batang semakin membesar dan perbedaan diameter tersebut berpengaruh langsung terhadap kemampuan stek membentuk akar, hal ini disebabkan adanya perbedaan variabilitas karbohidrat dan bahan tersimpan lainnya (Harsono, 2010). Adapun tujuan dari penelitian ini untuk mengetahui Pengaruh media tanam terhadap pertumbuhan stek mawar pagar (Rosa multiflora).

\section{BAHAN DAN METODE PENELITIAN}

Penelitian ini telah dilaksanakan di Gampong Panton Mesjid Kecamatan Makmur Kabupaten Bireuen pada bulan Maret sampai dengan Mei 2018. Alat yang digunakan dalam penelitian ini adalah cangkul, gembor, meteran, cutter, polybag, gembor, paranet, papan sampel, kamera, kalkulator, alat tulis dan peralatan lain yang diperlukan dalam penelitian. Bahan yang digunakan dalam penelitian adalah air kelapa, sekam padi, pupuk kandang 
sapi, tanah dan stek mawar. Rancangan yang dilakukan dalam penelitian ini adalah Rancangan Acak Kelompok (RAK) Non faktorial dengan perlakuan, yaitu penggunaan media tanam yang terdiri dari 3 taraf : $\mathbf{M}_{0}=$ Sekam, $\mathbf{M}_{1}=$ Tanah + Sekam, $\mathbf{M}_{2}=$ Tanah + sekam + pupuk kandang. Model matematika yang digunakan untuk Rancangan Acak

\section{HASIL DAN PEMBAHASAN \\ Pengaruh Media Tanam Umur Muncul Tunas (Hari)}

Rata-rata umur muncul tunas stek mawar pagar akibat pengaruh media tanam disajikan pada Tabel 1. Tabel 1 memperlihatkan bahwa media tanam berpengaruh tidak nyata terhadap pertumbuhan umur muncul tunas stek

Tabel 1. rata-rata umur muncul tunas stek mawar pagar akibat pengaruh media tanam

\begin{tabular}{lc}
\hline \multicolumn{1}{c}{ Perlakuan Media Tanam } & Umur Muncul Tunas (Hari) \\
\hline $\mathrm{M}_{0}=$ Sekam & 4,08 \\
$\mathrm{M}_{1}=$ Tanah + Sekam & 4,35 \\
$\mathrm{M}_{2}=$ Tanah + sekam + pupuk kandang $^{\mathrm{BNT}_{0,05}}$ & 3,85 \\
\hline
\end{tabular}

Pertumbuhan tanaman sangat dipengaruhi oleh kondisi dari media tanam yang juga disebut sebagai faktor adaptasi, dimana banyak terdapat faktor fisik dari media tersebut yang berpengaruh terhadap

\section{Panjang Tunas $(\mathrm{Cm})$}

Rata-rata panjang tunas stek mawar pagar akibat pengaruh media tanam disajikan pada Tabel 2. Tabel 2 memperlihatkan bahwa panjang tunas tertinggi pada umur 30 HST dan 60 HST dijumpai pada perlakuan media tanam $\mathrm{M}_{1}$, sedangkan panjang tunas terendah pada
Kelompok (RAK) Non Faktorial sebagai berikut $: \mathbf{Y i j}=+\boldsymbol{\beta} \mathbf{i}+\boldsymbol{\tau} \mathbf{j}+\boldsymbol{\varepsilon} \mathbf{i j k}$. Data hasil penelitian ini dianalisis dengan ANOVA dan dilanjutkan dengan Uji Beda Rataan menurut Duncan (DMRT). Pengamatan parameter dalam penelitian ini terdiri dari : umur muncul tunas, panjang tunas, jumlah tunas, panjang akar, jumlah akar, jumlah daun, persentase stek yang tumbuh.

mawar pagar. Hal ini diduga media tanam tidak dapat mempengaruhi terhadap pertumbuhan awal stek mawar pagar. Karena pada awal proses pertumbuhan stek mawar pagar unsur hara yang terdapat pada media tanam belum mampu mempengaruhi pertumbuhan umur muncul tunas stek mawar pagar.

\begin{tabular}{|c|c|c|}
\hline \multirow{2}{*}{ Perlakuan Media Tanam } & \multicolumn{2}{|c|}{ Panjang Tunas $(\mathrm{cm})$} \\
\hline & $30 \mathrm{HST}$ & $60 \mathrm{HST}$ \\
\hline $\mathbf{M}_{0}=$ Sekam & $1,62 \mathrm{a}$ & $1,86 \mathrm{a}$ \\
\hline $\mathbf{M}_{1}=$ Tanah + Sekam & $5,52 \mathrm{c}$ & $3,05 \mathrm{c}$ \\
\hline $\mathbf{M}_{2}=$ Tanah + sekam + pupuk kandang & $3,44 b$ & $2,42 b$ \\
\hline $\mathrm{BNT}_{0,05}$ & 1,22 & 0,33 \\
\hline
\end{tabular}

Keterangan : Angka yang diikuti oleh huruf yang sama pada lajur yang sama tidak berbeda nyata pada taraf $\mathrm{P} \leq 0,05$ (UJI BNT) 
Media tanam sekam dan tanah sering digunakan untuk media tanam tanaman karena memiliki beberapa kelebihan yaitu mudah mengikat air, tak mudah lapuk, sumber kalium (K) yang diperlukan tanaman, murah dan mudah didapat, dan tak mudah menggumpal alias memadat jadi akar tanaman bisa tumbuh dengan sempurna (Topan, 2010). Sekam padi merupakan limbah yang mempunyai sifat-sifat antara lain: ringan, drainase dan aerasi yang baik, tidak mempengaruhi $\mathrm{pH}$, ada ketersediaan hara atau larutan garam namun mempunyai kapasitas penyerapan air dan hara rendah dan harganya murah. Sekam padi mengandung unsur $\mathrm{N}$ sebanyak $1 \%$ dan K $2 \%$ (Rahardi, 2009).

Tanah tersusun oleh lapisan-lapisan yang disebut horizon tanah. Horizon tanah

\section{Jumlah Tunas (Tunas)}

Rata-rata jumlah tunas stek mawar pagar akibat pengaruh media tanam disajikan pada Tabel 3. Tabel 3 memperlihatkan bahwa jumlah tunas terbanyak pada umur 30 HST dan 60 HST dijumpai pada perlakuan media tanam $\mathrm{M}_{1}$, sedangkan jumlah tunas tersedikit pada dapat dibedakan berdasarkan batas perubahan antara horizon satu dengan yang lain. Makin gelap warna tanah berarti makin tinggi produktivitasnya dan cenderung lebih banyak menyerap energi matahari dibandingkan benda yang berwarna terang, sehingga akan lebih mendorong laju evaporasi. Tanah yang menjadi media tumbuh bagi tanaman memiliki komposisi seperti, karbohidrat (gula, selulosa, hemiselulosa), lemak (gliserida, asam-asam lemak, stearat dan oleat), dan lignin yang tersusun dari $\mathrm{C}, \mathrm{H}$, dan $\mathrm{O}$, juga oleh $\mathrm{N}, \mathrm{P}, \mathrm{S}, \mathrm{Fe}$, dan lain-lain, sedangkan bagian mineralnya terdiri dari unsur hara makro dan mikro esensial (Hanafiah dkk., 2003).

umur 30 HST dan 60 HST dijumpai pada perlakuan $\mathrm{M}_{0}$. Hal ini diduga media sekam dan tanah maupun mempengaruhi pertumbuhan vegetatif dan generatifnya lebih baik dibandingkan dengan media lain sehingga pertumbuhan jumlah tunas banyak.

Tabel 3. Rata-rata jumlah tunas stek mawar pagar akibat pengaruh media tanam

\begin{tabular}{lcc}
\hline \multirow{2}{*}{ Perlakuan Media tanam } & \multicolumn{2}{c}{ Jumlah tunas (Tunas) } \\
\cline { 2 - 3 } & $30 \mathrm{HST}$ & $60 \mathrm{HST}$ \\
\hline $\mathrm{M}_{0}=$ Sekam & $1,09 \mathrm{a}$ & $1,14 \mathrm{a}$ \\
$\mathrm{M}_{1}=$ Tanah + Sekam & $1,31 \mathrm{~b}$ & $1,36 \mathrm{~b}$ \\
$\mathrm{M}_{2}=$ Tanah + sekam + pupuk kandang $^{\prime}$ BNT $_{0,05}$ & $1,18 \mathrm{a}$ & $1,28 \mathrm{a}$ \\
\hline
\end{tabular}

Keterangan : Angka yang diikuti oleh huruf yang sama pada lajur yang sama tidak berbeda nyata pada taraf P $₫$, 05 (UJI BNT)

Media tanam merupakan komponen utama untuk bercocok tanam. Media tumbuh yang akan digunakan harus disesuaikan dengan jenis tanaman yang ingin ditanam. Menentukan media tumbuh yang tepat dan standar untuk jenis tanaman yang berbeda habitat asalnya merupakan hal yang sulit. Hal ini dikarenakan setiap daerah memiliki kelembaban dan kecepatan angin yang berbeda. Secara umum, media tumbuh harus dapat menjaga kelembaban daerah sekitar akar, menyediakan cukup udara, dan dapat menjamin ketersediaan unsur hara.

Media tanam memegang peranan penting bagi pertumbuhan dan kesehatan tanaman. Salah satu syarat media tanam yang baik adalah porositas yaitu kemampuan media dalam menyerap air dan steril. Tingkat porositas tanaman di 
setiap daerah berbeda-beda, didaerah dataran rendah yang berudara panas, tingkat penguapannya tinggi, media harus mampu menahan air sehingga tidak mudah kering. Media harus terbebas dari

\section{Jumlah Daun (Helai)}

Rata-rata jumlah daun stek mawar pagar akibat pengaruh media tanam disajikan pada Tabel 4. Tabel 4 memperlihatkan bahwa jumlah daun terbanyak pada umur 30 HST dan 60 HST dijumpai pada perlakuan media tanam $\mathrm{M}_{1}$, sedangkan jumlah tunas tersedikit pada organisme yang dapat menyebabkan penyakit, seperti bakteri, spora, jamur dan telur siput (Harsono, 2010).

umur 30 HST dijumpai pada perlakuan $\mathrm{M}_{0}$ dan pada umur 60 HST dijumpai pada perlakuan $\mathrm{M}_{2}$. Hal ini diduga media sekam dan tanah telah mampu mencukupi kebutuhan stek mawar pagar, karena pada perlakuan $\mathrm{M}_{1}$ memperlihatkan daun terbanyak dibandingkan dengan perlakuan yang lain.

Tabel 4. Rata-rata jumlah daun stek mawar pagar akibat pengaruh media tanam

\begin{tabular}{|c|c|c|}
\hline \multirow{2}{*}{ Perlakuan Media tanam } & \multicolumn{2}{|c|}{ Jumlah Daun (helai) } \\
\hline & $30 \mathrm{HST}$ & $60 \mathrm{HST}$ \\
\hline $\mathrm{M}_{0}=$ Sekam & $1,16 \mathrm{a}$ & $1,37 \mathrm{a}$ \\
\hline $\mathbf{M}_{1}=$ Tanah + Sekam & $1,73 b$ & $2,19 b$ \\
\hline $\mathbf{M}_{2}=$ Tanah + sekam + pupuk kandang & $1,62 b$ & $1,19 \mathrm{a}$ \\
\hline $\mathrm{BNT}_{0,05}$ & 0,20 & 0,26 \\
\hline
\end{tabular}

Keterangan : Angka yang diikuti oleh huruf yang sama pada lajur yang sama tidak berbeda nyata pada taraf $\mathrm{P} \leq$ 0,05 (UJI BNT)

Menurut Wuryaningsih dkk., (2008), media tumbuh tanah dan sekam berperan untuk memperbaiki struktur tanah jadi sistem aerasi dan drainase di media tanam menjadi lebih baik, perpaduan atau campuran antara kedua media tersebut memberikan dampak yang baik bagi tanaman. Media tumbuh yang tepat untuk stek mawar pagar harus dapat menjaga kelembaban daerah sekitar akar, menyediakan cukup udara dan dapat menahan ketersedian unsur hara.

Menurut pendapat Allorerung dkk., (2000) bahwa media tumbuh yang baik harus dapat menjamin perkembangan akar

\section{Jumlah Akar (Akar)}

Rata-rata jumlah akar stek mawar pagar akibat pengaruh media tanam disajikan pada Tabel 5. Tabel 5 memperlihatkan bahwa jumlah akar terbanyak pada umur 30 HST dan 60 HST dijumpai pada perlakuan media tanam $\mathrm{M}_{2}$, sedangkan jumlah akar paling sedikit pada umur 30 HST dijumpai pada perlakuan $\mathbf{M}_{0}$ dan dapat menyediakan unsur hara dan adanya ruang pori tanah dalam keadaan berimbang, dengan demikian kita harus dapat menciptakan struktur tanah remah. Media tumbuh tanah dan sekam akan dicerna oleh berbagai jasad renik yang ada di dalam tanah dan selanjutnya didekomposisi jika faktor lingkungan mendukung terjadinya proses tersebut, akibatnya adalah proses pelepasan unsur hara untuk kebetuhan tanaman semakin intensif, sehingga member dampak yang baik terhadap pertumbuhan tanaman (Manfarizah, 2006).

dan pada umur 60 HST dijumpai pada perlakuan $\mathbf{M}_{2}$. Hal ini perlakuan yang menggunakan media tanam tanah, sekam dan pupuk kandang mampu menyediakan banyak unsur hara yang dibutuhkan untuk pertumbuhan jumlah akar. Dibandingkan dengan media tanam tanah saja dan tanah kombinasi sekam, tanah kombinasi sekam dan pupuk kandang lebih memprlihatkan 
hasil yang lebih baik untuk pertumbuhan jumlah akar stek mawar pagar, karena media tanam tanah kombinasi sekam dan pupuk kandang memiliki daya serap air yang tinggi dan menyediakan banyak unsur hara sehingga kandungan air dan unsur hara yang dibutuhkan oleh stek mawar pagar tersimpan dengan baik untuk kebutuhan-kebutuhan organ-organ tanaman yang lain seperti akar dan daun.

Tabel 5. Rata-rata jumlah akar stek mawar pagar akibat pengaruh media tanam

\begin{tabular}{|c|c|c|}
\hline \multirow{2}{*}{ Perlakuan Media tanam } & \multicolumn{2}{|c|}{ Jumlah Akar (Akar) } \\
\hline & $30 \mathrm{HST}$ & $60 \mathrm{HST}$ \\
\hline $\mathrm{M}_{0}=$ Sekam & $4,62 \mathrm{a}$ & $10,70 \mathrm{a}$ \\
\hline $\mathbf{M}_{1}=$ Tanah + Sekam & $9,12 b$ & $17,95 b$ \\
\hline $\mathbf{M}_{2}=$ Tanah + sekam + pupuk kandang & $14,33 \mathrm{c}$ & $31,70 \mathrm{c}$ \\
\hline $\mathrm{BNT}_{0,05}$ & 2,15 & 1,70 \\
\hline
\end{tabular}

Keterangan : Angka yang diikuti oleh huruf yang sama pada lajur yang sama tidak berbeda nyata pada taraf $\mathrm{P} \leq 0,05$ (UJI BNT)

Media tanam merupakan komponen utama untuk bercocok tanam. Media tumbuh yang akan digunakan harus disesuaikan dengan jenis tanaman yang ingin ditanam. Menentukan media tumbuh yang tepat dan standar untuk jenis tanaman yang berbeda habitat asalnya merupakan hal yang sulit. Hal ini dikarenakan setiap daerah memiliki kelembaban dan kecepatan angin yang berbeda. Secara umum, media tumbuh harus dapat menjaga kelembaban daerah sekitar akar, menyediakan cukup udara, dan dapat menjamin ketersediaan unsur hara.

Media merupakan salah satu faktor luar yang sangat berpengaruh terhadap keberhasilan pembibitan stek. Hal ini disebabkan media dalam pembibitan

\section{Panjang Akar (cm)}

Rata-rata panjang akar stek mawar pagar akibat pengaruh media tanam disajikan pada Tabel 6 . Tabel 6 memperlihatkan bahwa panjang akar terbanyak pada umur 30 HST dan 60 HST dijumpai pada perlakuan media tanam $\mathrm{M}_{2}$, sedangkan panjang akar tersedikit pada umur 30 HST dijumpai pada perlakuan $\mathrm{M}_{0}$ dan pada umur 60 HST dijumpai pada perlakuan $\mathbf{M}_{2}$. Hal ini diduga perlakuan yang menggunakan media tanam tanah, sekam dan pupuk kandang mampu menyediakan banyak unsur hara yang merupakan salah satu faktor yang sangat berperan terhadap pertumbuhan awal, terutama terbentuknya akar. Sebagian unsur hara yang dibutuhkan tanaman tersebut dipasok dari media tanam. Media tanam yang baik memiliki komposisi yang tepat. Komposisi media tanam mempunyai kemampuan menyediakan unsur hara yang dibutuhkan tanaman dalam menunjang kebutuhan hidup stek mawar. Media yang baik untuk pertumbuhan stek yaitu beraerasi baik dan bebas hama penyakit, mengandung cukup bahan organik dan mampu menahan air yang tinggi, sehingga air yang diperlukan selama pertumbuhan awal selalu terpenuhi (Hardjowigeno, 2003).

dibutuhkan untuk pertumbuhan panjang akar. Hal ini diduga karena perlakuan $\mathrm{M}_{2}$ merupakan media yang baik dan ideal bagi pertumbuhan awal stek mawar, dimana media tersebut mempunyai struktur tanah yang baik dengan kandungan hara yang cukup sehingga mampu mendukung pertumbuhan awal stek mawar. Media tumbuh yang terdiri campuran tanah, sekam dan pupuk kandang mempunyai struktur yang baik, yaitu mempunyai perbandingan yang seimbang antara poripori tanah yang berisi udara dengan air. 
Tabel 6. Rata-rata panjang akar stek mawar pagar akibat pengaruh media tanam

\begin{tabular}{|c|c|c|}
\hline \multirow{2}{*}{ Perlakuan Media tanam } & \multicolumn{2}{|c|}{ Panjang Akar $(\mathrm{cm})$} \\
\hline & $30 \mathrm{HST}$ & $60 \mathrm{HST}$ \\
\hline $\mathrm{M}_{0}=$ Sekam & $5,05 \mathrm{a}$ & $8,67 \mathrm{a}$ \\
\hline $\mathbf{M}_{1}=$ Tanah + Sekam & $7,69 b$ & $15,96 b$ \\
\hline $\mathbf{M}_{2}=$ Tanah + sekam + pupuk kandang & $10,65 \mathrm{c}$ & $17,61 \mathrm{c}$ \\
\hline BNT $_{0,05}$ & 0,82 & 1,30 \\
\hline
\end{tabular}

Keterangan : Angka yang diikuti oleh huruf yang sama pada lajur yang sama tidak berbeda nyata pada taraf P $₫, 05(\mathrm{UJI} B N T)$

Kondisi demikian menyebabkan absorpsi hara dan air oleh tanaman berjalan dengan lancar sehingga pertumbuhan tanaman menjadi optimal. Pertumbuhan tanaman sangat dipengaruhi oleh kondisi dari media tumbuh yang juga disebut sebagai faktor adaptasi di mana

\section{Persentase Stek yang Tumbuh (\%)}

Rata-rata persentase stek mawar pagar yang tumbuh akibat pengaruh media tanam disajikan pada Tabel 7. Tabel 7 memperlihatkan bahwa persentase stek yang tumbuh paling banyak dijumpai pada banyak terdapat faktor fisik dari media tersebut yang berpengaruh terhadap pertumbuhan tanaman, antara lain aerasi, kandungan air tanah, selain itu terdapat pula zat makanan dalam media tersebut (Hardjowigeno, 2003).

perlakuan media tanam $\mathbf{M}_{1}$, sedangkan persentase stek yang tumbuh tersedikit dijumpai pada perlakuan $\mathbf{M}_{0}$. Hal ini diduga perlakuan yang menggunakan media tanam tanah dan sekam mampu mempengaruhi pertumbuhan stek mawar.

Tabel 7. Rata-rata persentase stek mawar pagar yang tumbuh akibat pengaruh media tanam

\begin{tabular}{lc}
\hline Perlakuan Media tanam & Persentase Stek yang Tumbuh (\%) \\
\hline $\mathrm{M}_{0}=$ Sekam & $58,32 \mathrm{a}$ \\
$\mathrm{M}_{1}=$ Tanah + Sekam & $84,72 \mathrm{c}$ \\
$\mathrm{M}_{2}=$ Tanah + sekam + pupuk kandang & $65,27 \mathrm{~b}$ \\
\hline BNT $_{0,05}$ & 20,09 \\
\hline Keterangan : Angka yang diikuti oleh huruf yang sama pada lajur yang sama tidak berbeda nyata \\
pada taraf $\mathrm{P} ₫$ ),05(UJI BNT)
\end{tabular}

Menurut Wuryaningsih dkk., (2008), media tumbuh tanah dan sekam berperan untuk memperbaiki struktur tanah jadi sistem aerasi dan drainase di media tanam menjadi lebih baik, perpaduan atau campuran antara kedua media tersebut memberikan dampak yang baik bagi tanaman. Media tumbuh yang tepat untuk stek mawar pagar harus dapat menjaga kelembaban daerah sekitar akar, menyediakan cukup udara dan dapat menahan ketersedian unsur hara.

$$
\text { Media tanam merupakan }
$$

komponen utama ketika akan bercocok tanam. Media tanam yang akan digunakan harus disesuaikan dengan jenis tanaman yang akan ingin ditanam. Menentukan media tanam yang tepat dan standar untuk jenis tanaman yang berbeda habitat asalnya merupakan hal yang sulit. Hal ini dikarenakan setiap daerah memiliki kelembapan dan kecepatan angin yang berbeda.Secara umum, media tanam harus dapat menjaga kelembapan daerah sekitar akar, menyediakan cukup udara, dan dapat menahan ketersediaan unsur hara.

\section{KESIMPULAN DAN SARAN \\ Kesimpulan \\ Media tanam berpengaruh sangat nyata terhadap pertumbuhan panjang tunas, jumlah tunas, jumlah daun, jumlah}


akar, panjang akar pada umur 30 HST dan 60 HST dan persentase stek yang tumbuh. Perlakuan terbaik dijumpai pada perlakuan menggunakan media tanam tanah dan sekam $\left(\mathrm{M}_{1}\right)$

\section{Saran}

Untuk budidaya stek mawar dapat mengkombinasikan media tanam tanah dan sekam $\left(\mathrm{M}_{1}\right)$ pada waktu dan lokasi yang berbeda.

\section{DAFTAR PUSTAKA}

Alamanda. 2009 “"Bunga Mawar

"(online).http://www.citraindahruma hku.com/bunga-mawar/, diakses tanggal 10 April 2018).

Allorerung, D., Amrizal, E.T., Tenda, R.B., Maliangkay, L.A., Hosang, R.H., Akuba, N.L., Barri., Abner, L. 2000. Petunjuk Teknis Budidaya Tanaman Kelapa Dalam (Cocos nusifera). Balai Penelitian Tanaman Kelapa dan Palma Lain. Cetakan ketiga 2000. Hanafiah, K., Anas, I., Napoleon, A., Ghoffar, N. 2003. Biologi Tanah. Raja Grafindo Persada. Jakarta
Hardjowigeno, S. 2003. Ilmu Tanah. Akademika Pressindo, Jakarta.

Harsono, S. 2010. Perbanyakan tanaman sirih. Warta Tumbuhan Obat Indonesia.1(1).

Manfarizah. 2006. Pengaruh Beberapa Jenis Bokashi dan Dosis terhadap Pertumbuhan Status Hara Makro (N, P dan K) Tanah Salin dan Pertumbuhan Tanaman Jagung (Zea mays L.) Jurnal Agrista 10(1).

Rahardi, F. 2009. Hidroponik semakin canggih. Trubus : XXII (264).

Wuryaningsih, R., Prasetya, J., Utami, P.K. 2003. Penampilan Empat Kultivar Mawar Potong pada Media Tanam Organik dalam Kultur Agregat Hidroponik. Jurnal Hortikultura. (Ed. Khusus) 14.

Topan. 2010. "Akreditasi Sekolah". http://atopatonblog.com./2010/01/ akreditasi-sekolah.html. Diakses pada tanggal 8 Januari 2018. 